\title{
Recovery of nigrostriatal dopaminergic system insufficiency by allotransplantation of embryonic brain tissue
}

\author{
Olga Berchenko*, Yelena Usmentseva \\ The Laboratory of Neurophysiology, Immunology and Biochemistry, Institute of Neurology, Psychiatry and Narcology of the NAMS, \\ Kharkiv, Ukraine \\ Email: "berchenko.olga@mail.ru
}

Received 9 July 2013; revised 5 August 2013; accepted 25 August 2013

Copyright (C) 2013 Olga Berchenko, Yelena Usmentseva. This is an open access article distributed under the Creative Commons Attribution License, which permits unrestricted use, distribution, and reproduction in any medium, provided the original work is properly cited.

\begin{abstract}
In an experiment in rats with electrolytic lesion of the compact part of substantia nigra (SN) and after allotransplantation of the embryonic tissue of $\mathrm{SN}$ in the caudate nucleus the features of movement and emotional behavior in the Open Field Test (OFT), the rotation movements caused by an administration of amphetamine, a content of catecholamines in the caudate nucleus, hypothalamus and blood plasma have been investigated. It is shown that the electrolytic lesion causes violations of the statokinetic reflexes, the horizontal and the vertical movement activity, enhances the rotatory behavior, slow the orienttate-searching and the emotional reactions that combined with disbalance in dopamine- and noradrenalinetransmitter systems functioning. Allotransplantation of the embryonic dofaminsynthesizing brain tissue contributes to the restoration of movement activeity and its specific neurotransmitter ensuring.
\end{abstract}

Keywords: Movement Violations; Catecholamines; Allotransplantation; Embryonic Tissue

\section{INTRODUCTION}

Degeneration of dopaminergic neurons of the brain nigrostriatal system is key one in mechanisms of extrapyramidal violations occurrence during Parkinson's disease. Among the many causing dopaminergic neurons, death factors are leading the genetic predisposition, the aging, the exogenous impacts [1-3]. The insufficiency of dopamine synthesis in SN results to changes in the functional relationships between content of dopamine and

\footnotetext{
"Corresponding author.
}

glutamate. At the same time, the glutamate receptor hyperactivation results to increase of the calcium ions permeability into dopamine neuron that causing its damage and death [4]. The progressive decrease in activity of the dofaminsynthesizing neurons associated with the dysfunction in other neurotransmitter systems. It is noted that a reduction in synthesis of noradrenaline in the locus coeruleus neurons and serotonin in neurons of the raphe nucleus of brain stem [5-7].

Prevention of further dopaminergic neurons death and recovery of functional activity of neurons that synthesize noradrenaline and serotonin is possible by using specific dopaminergic pharmacotherapy. At the same time, prolonged use of the replacement therapy is associated with the progress of the side peripheral and central neurotoxic effects. Recently as the pathogenesis-based therapy has been achieved good effects in the conditions of use of the tissues and cells neurotransplantation method. It is shown that neurotransplantation results to increase in a number of dopaminergic neurons, stimulates regeneration processes in the nigrostriatal pathway and reinnervation of striatum [8-11]. The advantage of embryonic neural tissue transplantation over other neurotransplantation biotechnologies causes by nerve cells contained in the graft have a high level of engraftment [12], form the functional connections with recipient tissue $[13,14]$ and produce specific neurotransmitters [15]. The embryonic tissue neurografts produce growth factors in physiological concentrations that required for regenerative processes stimulation such as: NGF (nerve growth factor), BDNF (brain-derived neurotrophic factor), BFGF (basic fibroblast growth factor) $[16,17]$. These factors in a norm support the differentiation of nerve cells, the growth of axons and dendrites, regulate neuronal migration processes, providing neuroprotective effects on dopaminergic 
neurons, stimulate local regenerative processes [11,18].

The graft localization is important for the functional recovery of the nigrostriatal pathway. In our previous studies, it has been shown that a cortical placement of the dopaminergic graft in rats with the bilateral lesion of the compact part of $\mathrm{SN}$ reduces postural asymmetry and movement violations [19].

Aim of this study was to investigate influence of introcaudal transplantation of the embryonic dofaminsynthesizing brain tissue on dynamics of motor functions recovery and content of biogenic monoamines in rats with unilateral lesion of the compact part of SN.

\section{MATERIALS AND METHODS}

Investigations were carried out in 30 nonlinear white mature male rats ( 8 months) of age weighing from 300 to 370 g. Keeping animals and manipulations with them were carried out in accordance with "General ethical principles of animal experiments", approved at the I National Congress of Bioethics (Kiev, 2011), "European Convention for the Protection of Vertebrate Animals used for Experimental and other Scientific Purposes" (Strasbourg, 1986), and in accordance with the requirements and the provisions of the ethics of the Ministry of Health of Ukraine № 690 dated from 23.09.2009, the animals have been distributed into three groups: the I group ( $\mathrm{n}=$ 10 , control) - the intact rats; the II group $(n=10)$ - the rats with unilateral lesion of the compact part of SN; the III group $(\mathrm{n}=10)$ - the rats with unilateral lesion of the compact part of SN and allotransplantation in the caudate nucleus of the embryonic tissue of SN.

Extrapyramidal violations were modeled through unilateral lesion of the compact part of SN by electric current with intensity ranged from 3 to $4 \mathrm{~mA}$ for 15 seconds. Stereotactic coordinates of the compact part of SN were determined by the maps of the brain by E. Fifkova and D. Marshall (cited by J. Bures) [20], which corresponded to the distance from the point of intersection of the sagittal suture and bregma (zero point): in the rear direction- 4.0 $\mathrm{mm}$, laterally-2.0 $\mathrm{mm}$, in depth $-8.1 \mathrm{~mm}$.

For allotransplantation it used the 19 - 20-day gestation period embryonic tissue of $\mathrm{SN}$ with weight ranged from 8 to $10 \mathrm{mg}$ which was administered via a cannula in the caudate nucleus. Stereotaxic coordinates of the caudate nucleus were: $\mathrm{AP}-2.0 \mathrm{~mm}$ (in a forward direction from zero point), laterally $-2.0 \mathrm{~mm}$, in depth-3.5 mm [20]. The time from embryonic tissue fence to implantation ranged from 3 to 5 minutes.

Stereotaxic operations were performed under the general anesthesia of rats by using of the intraperitoneal injections of ketamine, $100 \mathrm{mg} / \mathrm{kg}$ of body weight.

Movement and emotional reactions of animals were investigated using OFT by testing each rat for $5 \mathrm{~min}$. [21]. It was recorded the following parameters of move- ment activity: the latent period of the first crossing of the square, the latent period of getting to the center, the number of crossed peripheral and central squares, the vertical activity (the number of vertical sets), grooming, orientate-searching reactions, emotional and vegetative reactions. The activity coefficient was determined by the formula:

$$
\mathrm{AI}=\mathrm{N} / \mathrm{t}_{1}+\mathrm{t}_{2},
$$

where $\mathrm{AI}$ - the activity index; $\mathrm{N}$ - the number of crossed squares in $3 \mathrm{~min} ; \mathrm{t}_{1}$ - the latent period of the first crossing of the square; $t_{2}$ - latent period of getting to the center.

An assessment of extrapyramidal violations and their restoration was performed by using the rotation test after intraperitoneal administration to rats of amphetamine in a dose $5 \mathrm{mg} / \mathrm{kg}$ of body weight [22].

A content of catecholamines in the brain structures and blood plasma were determined in the intact rats (the I group), in 30 days after electrolytic lesion of the compact part of SN (the II group), in 30 days after electrolytic lesion of the compact part of SN and in 30 days after allotransplantation of the embryonic tissue of SN in the caudate nucleus (the III group). In the decapitated animals were isolated brains on a cold, dividing them into structures and separating the caudate nucleus and the hypothalamus. The brain tissues were homogenized in the chilled double-distilled water by a glass microgomogenizator with a glass pestle. After centrifugation at $4000 \mathrm{~g}$ under $\mathrm{t}=4^{\circ} \mathrm{C}$ during 10 minutes concentration of catecholamines in supernatant and blood plasma was determined (adrenaline, noradrenaline, dopamine, the tissue eluates final dilution is 1:60) by using a competitive solid phase immunosorbent method on microtiter plates with the test systems 3-CAT ELISA (LDN, Germany). Optical density measurement of test samples was performed in the microplate analyzer GBG Stat FAX 2100 (USA) at a wavelength of $405 \mathrm{~nm}$.

Obtained results were statistically processed on PC with paired Wilcoxon criterion and Student criterion by using grouping data and mathematical analysis Microsoft Excel software.

\section{RESULTS AND DISCUSSION}

Unilateral electrolytic lesion of SN in $95 \%$ of the animals resulted to violation of the statokinetic reflexes-postural asymmetry in the form of slope head to the side, the spine hump-shaped bending and the raised tail reaction. The animals were lethargic, indecisive in movement act implementation, marked time or made circular movements (which are interrupted by the frequent pauses). On the 9th day after the lesion of SN in response to the amphetamine administration a number of rotation movements in 60 seconds ranged from 4 to 6 and after the 17 th to the 30 th days a number of rotations increased to 
range from 18 to 20 in 60 seconds.

Study of behavior of the rats in the OFT revealed a significant increase in the latent period of the first crossing of the square versus background indicators. Horizontal and vertical movement activity, the coefficient of activity were significantly $(\mathrm{p}<0.05)$ decreased on the 30 th day after the lesion of SN (Figure 1).

There were noted the vertical sets with rat's forepaws abut against the wall that can be viewed as a manifestation of an adaptive component. The lesion of SN resulted to decrease of the orientate-searching reactions, the manifestations of anxiety and fear, the reduction of animal grooming. Investigation of the rats behavior with the lesion of SN and allotransplantation into the caudate nucleus of the embryonic brain tissue, that produced dopamine, made possible reveal within 30 days of observations a positive dynamics in recovery of the statokinetic reflexes, the movement programs of targeted behavioral acts, the orientate-searching and the emotional reactions. The expressed positive dynamics of neurotransplantation effects was persisted within 30 days after implantation of the brain tissue. Testing animals in the Open Field revealed a significant $(p<0.05)$ decrease of the latent period of the first crossing of the square, the increase of the activity coefficient versus background of their values after the lesion of the compact part of SN (Figure 1). During this period the levels of orientate-searching reactions and positive grooming were elevated. An amphetamine administration to these rats did not cause any rotational movements. Sometimes the movement reactions were noted in the form of insignificant rotation of the body or the head to the side.

Study of catecholamines in the brain structures and blood plasma of the rats with the lesion of SN showed a significant decrease of dopamine level in the caudate nucleus and blood plasma in comparison with its values in the intact animals and its significant increase under influence of the embryonic dopaminesensitizing tissue allotransplantation in the caudate nucleus. A content of dopamine in hypothalamus in animals of the control and the experimental groups practically unchanged (Figure 2).

In the animals with lesion of the compact part of SN and the embryonic tissue allotransplantation versus the lesion of SN background significant changes in content of adrenaline and noradrenaline in the caudate nucleus and adrenaline in hypothalamus did not revealed (Figures 3 and 4). However noradrenaline concentration in blood plasma of the animals with the lesion of the compact part of SN had $43 \%$ increase in comparison with the intact rats indicators, the embryonic dopaminesensitizing tissue allotransplantation contributed to restoration of the adre-renaline concentration to the control values level (Figure 4).

Under influence of the embryonic dopaminesensitizing tissue allotransplantation in the caudate nucleus revealed a trend to normalization of the aggregate relation of the adrenaline and the noradrenaline to the dopamine coefficient values. Reducing of noradrenaline concentration in hypothalamus of the animals caused by the transplantation resulted to increase of the ratio coefficient of adrenaline and noradrenaline and decrease of the sum coefficient of adrenaline and noradrenaline to dopamine (Figure 5).

The results of carried out experimental studies shows that the electrolytic lesion of the compact part of $\mathrm{SN}$ causes the gross violations of the motor behavior of the rats that have manifested in violations of the statokinetic reflexes, in decrease of the vertical motor activity, in enhancement of the behavior of rotation (during use of the amphetamine test), in deceleration of the orientatesearching and the emotion reactions, that results to per-

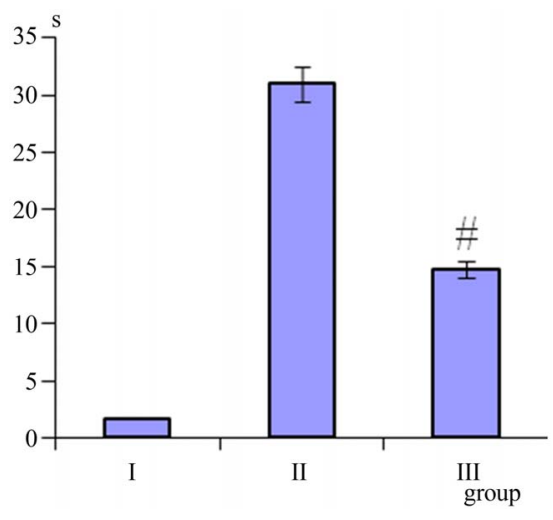

(a)

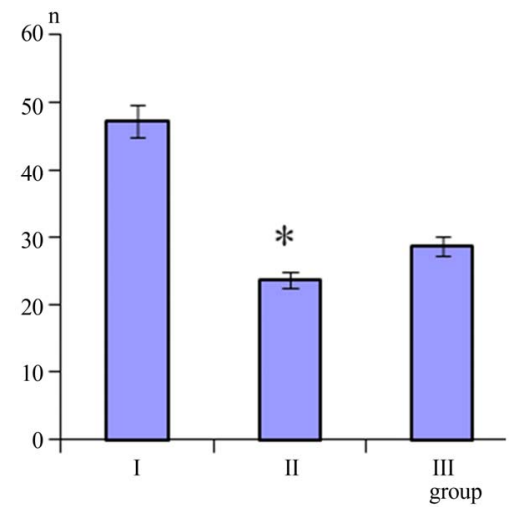

(b)

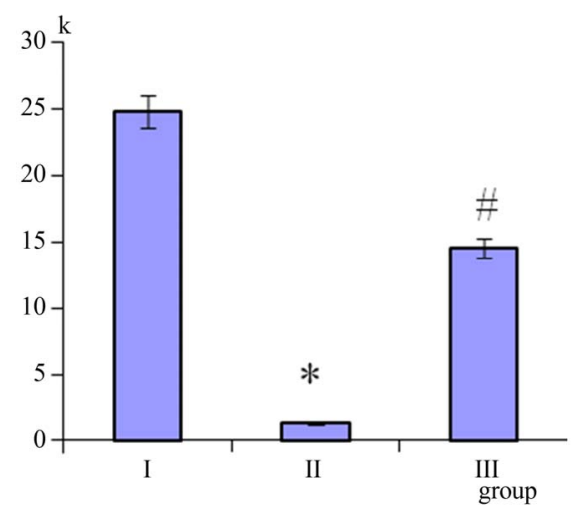

(c)

Figure 1. Changes in values of the latent periods of motion occurrence (a) the horizontal activity (b) and the activity coefficients (c) recorded during OFT among of the intact rats (I), with electrolytic lesion of the compact part of SN (II) and after administration of the embryonic dopaminsensitizing brain tissue into the caudate nucleus at the 30 th day after the neurotransplantation (III) $\left({ }^{*} \mathrm{p}<0.05\right.$ compared to the I group, ${ }^{\#} \mathrm{p}<0.05$ compared to the II group). 


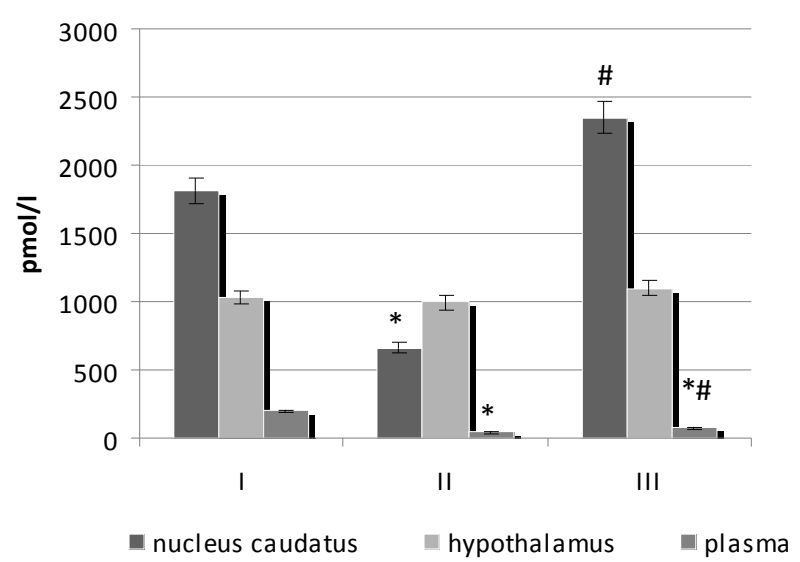

Figure 2. Dopamine content in the caudate nucleus, hypothalamus and blood plasma of the rats. (a) The intact group; (b) The group with electrolytic lesion of the compact part of SN; (c) The group with electrolytic lesion of the compact part of SN and transplantation of the embryonic brain tissue into the caudate nucleus $\left({ }^{*} \mathrm{p}<0.05\right.$ compared to the norm, ${ }^{\#} \mathrm{p}<0.05 \mathrm{com}-$ pared to the lesion).

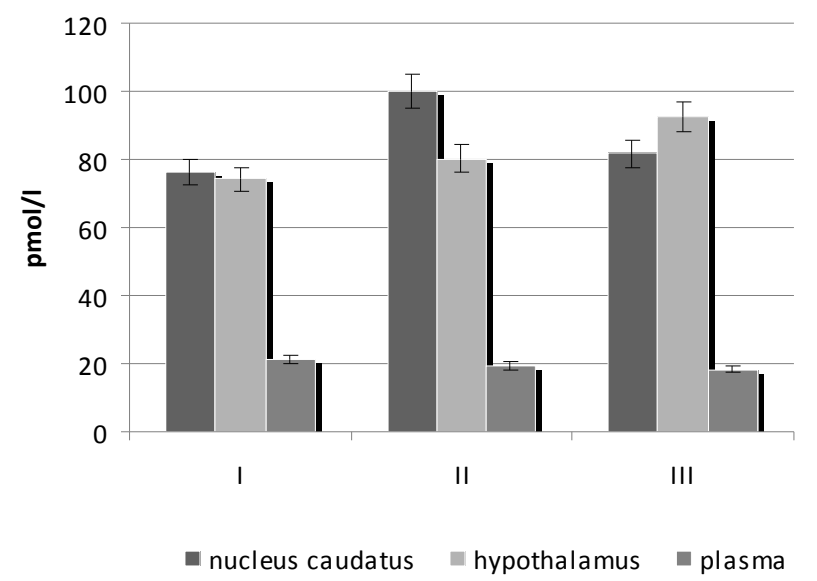

Figure 3. Adrenaline content in the caudate nucleus, hypothalamus and blood plasma of the rats. (a) The intact group; (b) The group with electrolytic lesion of the compact part of SN; (c) The group with electrolytic lesion of the compact part of SN and the embryonic brain tissue transplantation into the caudate nucleus $\left(^{*} \mathrm{p}<0.05\right.$ compared to the norm, ${ }^{\#} \mathrm{p}<0.05$ compared to the lesion).

sistent disbalance in functioning of the dopamine- and the noradrenalinesynthesizing systems. Significant decrease of dopamine level in striatum, based on the literature data [23-25], represent morphological and functional abnormalities in the nigrostriatal system of the brain and as a result there is progress of the movement violations. Changes in the metabolism of noradrenaline and adrenaline less expressed apparently due to adrenergic neurons minor affections that occur during an electrolytic modeling of the nigrostriatal insufficiency. At the same time revealed $\mathrm{A}+\mathrm{NA} / \mathrm{DA}$ ratio changes perhaps due to violations of the mediators synthesis or the release from re-

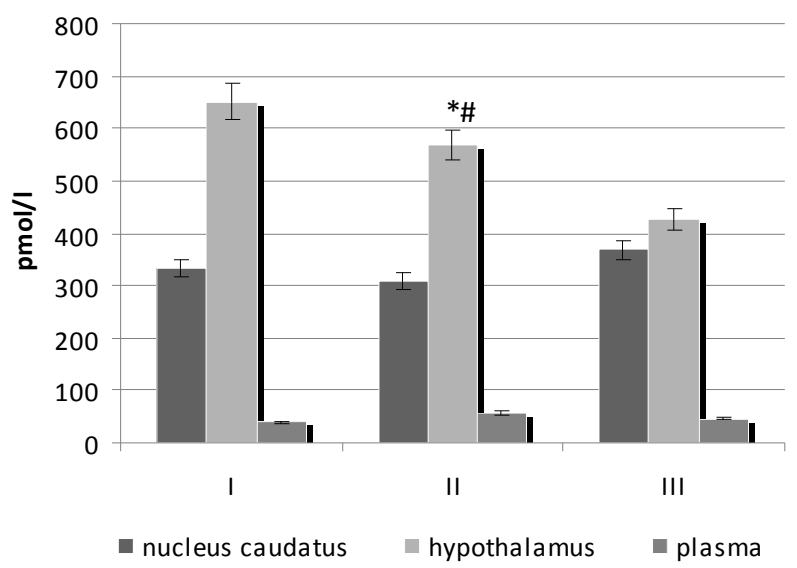

Figure 4. Noradrenaline content in the caudate nucleus, hypothalamus and blood plasma of the rats. (a) The intact group; (b) The group with electrolytic lesion of the compact part of SN; (c) The group with electrolytic lesion of the compact part of SN and the embryonic brain tissue transplantation into the caudate nucleus $\left({ }^{*} \mathrm{p}<0.05\right.$ compared to the norm, ${ }^{\#} \mathrm{p}<0.05$ compared to the lesion).

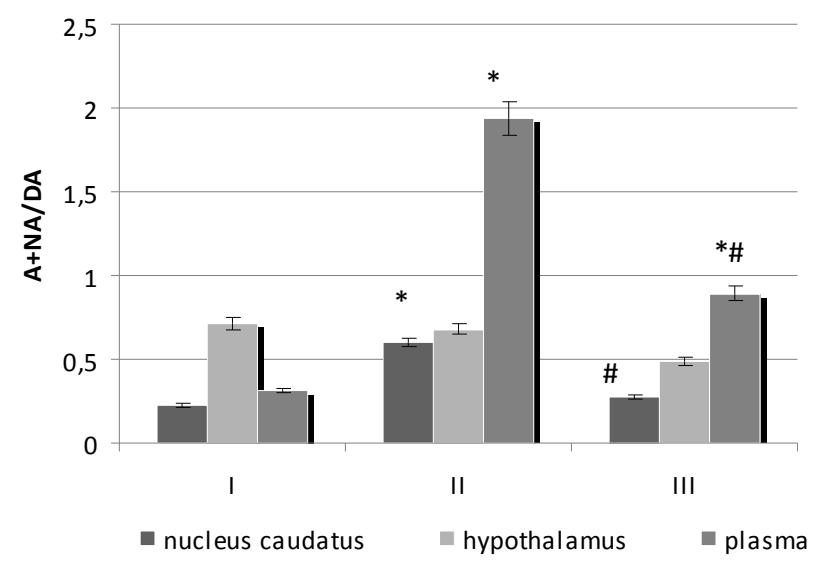

Figure 5. The concentration ratio of adrenaline and noradrenaline to dopamine in the caudate nucleus, hypothalamus and blood plasma of the rats. (a) The intact group; (b) The group with electrolytic lesion of the compact part of SN; (c) The group with electrolytic lesion of the compact part of SN and the embryonic brain tissue transplantation into the caudate nucleus $\left({ }^{*} \mathrm{p}\right.$ $<0.05$ compared to the norm ${ }^{\#} \mathrm{p}<0.05$ compared to the lesion).

serve granules, the mediator-receptors interactions, the presynaptic membrane reuptake of neurotransmitters, the mediator catabolism [26].

Introcerebral implantation of the embryonic dopaminesynthesizing tissue into striatum to the animals with the lesion of the compact part of SN has positive influence on movement behavior, orientate-searching and emotional reactions of the rats. Corrective neurotransplantation effects on locomotor system were traced in the 14 days after implantation. During this period this is caused apparently by integration of the embryonic dopamine producing tissue in the brain integrative activity 
with the donor tissue genetic program implementation in the tissue microenvironment which structurally and functionally related to it. The neurograft functioning and its neuromediator profile safe represent data of the positive recovery dynamics of the movement activity of the rats that was noted at the 30th day after the transplantation and the elevated levels of dopamine in striatum after the 30th day of allotransplantation and the A+NA/DA ratio decrease. Thus, carried out embryonic tissue allotransplantation by us stimulates recovery processes of neurotransmitter background in the nigrostrial system in the rats during movement violations modeling.

At the same time, the role of a wide variety of trophic and informational factors of the embryonic brain tissue in these processes can not be excluded.

\section{ACKNOWLEDGEMENTS}

The authors would like to thank and acknowledge Professor Tamara Vorobyova for mentoring, expertise and invaluable advices.

\section{REFERENCES}

[1] Maries, E. and Kordower, J.H. (2002) Etiology of Parkinson's disease: Genetics and environment revisited. Proceedings of the National Academy of Sciences, 99, 13972-13974. http://dx.doi.org/10.1073/pnas.242594999

[2] Соломинский, П.А., Милосердова, О.В. and Попова, С.Н. (2003) Анализ делеций мутаций в гене PARK2 при идиопатической форме болезни Паркинсона. Генетика, 2, 223-228.

[3] McGeer, P.L., McGeer, E.G. and Suzuki, J.S. (1977) Aging and extrapyramidal function. Archives of Neurology, 34, 33-35.

http://dx.doi.org/10.1001/archneur.1977.00500130053010

[4] Карабань, И.Н. (2006) Применение леводопосодержащих препаратов на современном этапе лечения болезни Паркинсона. Международный неврологический журнал, 6, 16-20.

[5] Jellinger, K.A. (1991) Pathology of Parkinson's disease. Changes other than the nigrostriatal pathway. Molecular and Chemical Neuropathology, 14, 153-197. http://dx.doi.org/10.1007/BF03159935

[6] Hoogendijk, W.J., Pool, C.W., Troost, D., et al. (1995) Image analyser-assisted morphometry of the locus coeruleus in Alzheimer's disease, Parkinson's disease and amyotrophic lateral sclerosis. Brain, 118, 131-143. http://dx.doi.org/10.1093/brain/118.1.131

[7] Halliday, G.M., Blumbergs, P.C., Cotton, R.G., et al. (1990) Loss of brainstem serotonin- and substance P-containing neurons in Parkinson's disease. Brain Research, 510, 104-107. http://dx.doi.org/10.1016/0006-8993(90)90733-R

[8] Björklund, A. and Gage, F.H. (1985) Neural grafting in animal models of neurodegenerative diseases. Annals of the New York Academy of Sciences, 457, 53-81. http://dx.doi.org/10.1111/j.1749-6632.1985.tb20799.x
[9] Чехонин, В.П., Белопасов, В.В., Дмитриева, Т.Б. and Баклаушев, В.П. (1999) Трансплантация эмбриональной нервной ткани в терапии Паркинсонизма: Современное состояние проблемы. Журнал неврологии и психиатрии, 11, 60-66.

[10] Угрюмов, М.В. (2001) Экспериментальная и клиническая нейротрансплантация-современное состояние и перспективы. Наука долголетия, 1, 9-17.

[11] Clarke, C.E. (2004) Neuroprotection and pharmacotherapy for motor symptoms in Parkinson's disease. The Lancet Neurology, 8, 466-474. http://dx.doi.org/10.1016/S1474-4422(04)00823-3

[12] Kordower, J.H., Freeman, T.B., Snow, B.J., et al. (1995) Neuropathological evidence of graft survival and striatal reinnervation after the transplantation of fetal mesen- cephalic tissue in a patient with Parkinson's disease. The New England Journal of Medicine, 332, 1118-1124. http://dx.doi.org/10.1056/NEJM199504273321702

[13] Lund, R.D. and Hauschka, S.D. (1976) Transplanted neural tissue develops connections with host rat brain. Science, 4253, 582-584. http://dx.doi.org/10.1126/science.959815

[14] Dunnett, S.B., Ryan, C.N., Levin, P.D., et al. (1987) Functional consequences of embryonic neocortex transplanted to rats with prefrontal cortex lesions. Behavioral Neuroscience, 101, 489-503. http://dx.doi.org/10.1037/0735-7044.101.4.489

[15] Nikkhah, G., Cunningham, M.G., McKay, R. and Björklund, A. (1995) Dopaminergic microtransplants into the substantia nigra of neonatal rats with bilateral 6-OHDA lesions. II. Transplant-induced behavioral recovery. The Journal of Neuroscience, 15, 3562-3570.

[16] Nieto-Sampedro, M., Lewis, E.R., Cotman, C.W., et al. (1982) Brain injury causes a time-dependent increase in neuronotrophic activity at the lesion site. Science, $\mathbf{4 5 6 2}$, 860-861. http://dx.doi.org/10.1126/science.7100931

[17] Чехонин, В.П., Лебедев, С.В., Волков, А.В., Павлов, К.А., $u \partial p$. (2010) Активация экспрессии мозгового нейротрофического фактора в зоне имплантации аллогенных и ксеногенных стволовых (прогениторных) клеток нервной ткани у крыс с ишемическим корковым инсультом. Клеточные технологии в биологии и медицине, 4, 195-198.

[18] Giacobini, M.M. (1993) Growth factors and the developing central nervous system: In vivo studies utilizing intraocular brain tissue transplantation with special reference to differential trophic effects of the IGF, FGF and PDGF families.

[19] Берченко, О.Г. and Тіткова, А.М. (1998) Нейробіологічні особливості впливів нейротрансплантації та дистантної імплантації ембріональної тканини substantia nigra при моделюванні екстрапірамідної патології. Фізіологічний журнал, 44, 17.

[20] Буреш, Я., Петрань, М. and Захар, И. (1962) Электрофизиологические методы исследования.

[21] Hall, C.S. (1936) Emotional behavior in the rat. III. The relationship between emotionality and ambulatory activity. Journal of Comparative Psychology, 22, 345-352. http://dx.doi.org/10.1037/h0059253 
[22] Буреш, Я., Бурешова, О. and Хьюстон, Д.П. (1991) Методики и основные эксперименты по изучению мозга и поведения.

[23] Henning, J., Strauss, U., Wree, A., et al. (2008) Differential astroglial activation in 6-hydroxydopamine models of Parkinson's disease. Neuroscience Research, 62, 246-253. http://dx.doi.org/10.1016/j.neures.2008.09.001

[24] Hirsch, E.C., Hunot, S. and Hartmann, A. (2005) Neuroinflammatory processes in Parkinson's disease. Parkinsonism \& Related Disorders, 11, 9-15.

http://dx.doi.org/10.1016/j.parkreldis.2004.10.013
[25] Yang, J., Sadler, T.R., Givrad, T.K., et al. (2007) Changes in brain functional activation during resting and locomotor states after unilateral nigrostriatal damage in rats. Neuroimage, 36, 755-773.

http://dx.doi.org/10.1016/j.neuroimage.2007.03.010

[26] Доведова, Е.Л. (2008) Активность дофаминергической системы мозга при введении экзогенного ДОФА. Журнал неврологии и психиатрии им. С.С. Корсакова, 9, 73-75. 